\title{
Concomitant sexually transmitted diseases in patients with newly diagnosed HIV in Sri Lanka
}

\author{
SD Dharmaratne ${ }^{*}$, K Buddhakarale \\ From 17th International Symposium on HIV and Emerging Infectious Diseases (ISHEID) \\ Marseille, France. 23-25 May 2012
}

\section{Introduction}

Diagnosing and treating STI are important both for the health of HIV infected persons, their sexual partners and for HIV prevention efforts. STI following an HIV diagnosis or STI co-infection can serve as a surrogate indicator of continued risk behaviors.

\section{Objective}

To determine the prevalence of concomitant STI in newly diagnosed HIV positive patients.

\section{Method}

Data was extracted from randomly selected individual clinical notes of patients who are attending the Central HIV clinic, Colombo.

\section{Results}

A total of 187 subjects were included to the study of which $106(57 \%)$ were males and 80 (43\%) were females. The mean age of the sample was 37 years (SD $=9.3$ ) and the median CD4 count at diagnosis was 320 cells $/ \mu$ l. Routine STI screening had been done only in 90.3\% (169) of the sample. Among the screened subjects for STIs, over one in every four (28\%) had an STI. Ulcerative and non-ulcerative STIs were present in $18.2 \%$ and $10 \%$ of subjects respectively. Syphilis was positive in $9.5 \%(\mathrm{~N}=16)$, symptomatic Herpes simplex infection in $7.7 \%(\mathrm{~N}=13)$, non gonoccocal urithritis /cervicitis in $6.5 \%(\mathrm{~N}=11)$ and symptomatic genital warts in $3 \%(\mathrm{~N}=5)$. There was a statistically significant association between the number of life time partners and STI prevalence $(\mathrm{P}=0.011)$ and sexual orientation and STI prevalence $(\mathrm{P}=0.005)$. In contrast gender, marital status and age did not show any statistically significant association with STI prevalence.

\footnotetext{
* Correspondence: sanjiva6@yahoo.com

National STD AIDS Control Program, Sri Lanka
}

\section{Conclusion}

Significant numbers of HIV patients are co-infected with at least one ulcerative or non-ulcerative STI at the time of their HIV diagnosis which enhances HIV transmission. Therefore, careful and continued screening and management of STIs in HIV positive patients is an important HIV prevention intervention.

Published: 25 May 2012
Submit your next manuscript to BioMed Central and take full advantage of:

- Convenient online submission

- Thorough peer review

- No space constraints or color figure charges

- Immediate publication on acceptance

- Inclusion in PubMed, CAS, Scopus and Google Scholar

- Research which is freely available for redistribution
C Biomed Central

\section{() Biomed Central}

